\title{
THE EFFECT OF ORGANIZATIONAL CULTURE ON ORGANIZATIONAL EFFECTIVENESS: CASE STUDY ON HOTEL-X JAKARTA
}

\author{
Alvin Liputra, Munawaroh. \\ Swiss German University \\ alvin.liputra@sgu.ac.id, munawaroh.zainal@sgu.ac.id
}

\begin{abstract}
Over a decade, the study of organizational culture and organization effectiveness has become more important and interesting. Organizational culture is formed through the behavior and beliefs of each person in one organization, while organizational effectiveness can ensure continuity of an organization's life and survival (Dizgah, 2011). Although many scholars have conducted study about organizational culture and organizational effectiveness, there is little attention given to this study in hotel industry, especially in Indonesia. An introduction of the relationship between the organizational culture and organizational effectiveness has been established in conceptual framework, with a case study in one of five stars hotel in Jakarta. Then, the understandings of theoretical are translated into Structural Equation Modelling (SEM) model. The SEM analysis discloses that there is significant influence of organizational culture to the organizational effectiveness and strategic direction tends to be the strongest factor loading of organizational culture that affects organizational effectiveness significantly.
\end{abstract}

Keywords: organizational culture, organizational effectiveness, strategic direction, hotel industry.

\section{Introduction}

Human are social beings, it is stated that people join various organizations or companies in most aspects of their lives as the relationship between individuals can be strongly arranged within organizations. In this case, organizations are socially constructed systems of human activity which focus on social processes. This concludes that an organization should satisfy the needs of the people in collaboration with the working environment. As the working environment has a lot of complexities, it can help an organization to search for more efficient ways to explore their working environment and improve the effectiveness of the organization. In order to know whether an organization is effective or not, there are a number of perspectives theories regarding how to measure the effectiveness of an organization. The measurement of effectiveness can be analyzed by some indicators. Those are customers orientation, employee satisfaction, organizational commitment, and financial \& growth performance. In addition, an organization's 
effectiveness can also be analyzed from the organizational culture point of view (Aydin \& Ceylan, 2009).

Several scholars have already conducted studies of organizational culture and effectiveness in particular industries. Over a decade, the study of organizational culture has become more important and more interesting. It is known that organizational culture has great impacts on businesses. In this study, various dimensions of organization culture will be analyzed, as it is known that culture is a very wide concept with many elements which differ according to the business type itself. Organizational culture can be formed through the behavior and beliefs of each person in the organization. Since people are working under the same conditions, the formed culture allows them to understand each other and work effectively (Aydin \& Ceylan, 2009).

This study has selected the hospitality industry specifically in the hotel sector to be the main research subject since in today's globalization era, the hospitality industry has become one of the world's largest employers and arguably one of the largest traders of foreign currency (Dwimantika, 2011). It plays a very important role in the global economy. In the hotel industry, staffs are relatively employed to operate the business, often in a 'shift' basis (Dwimantika, 2011). Yet in Indonesia, the employees in hospitality companies may consist of various people from different background and ethnic group with a diverse culture (Muktiono, 2013).

This research will be conducted in a large five stars hotel in Jakarta where the organization culture plays an important role as a major asset in reaching their organizational effectiveness. The hotel should also employ at over a hundred employees due to the large number of respondents required for data analysis.

\section{Literature Review}

\section{Organizational Culture}

The study of organizational culture has been identified by many scholars as a multi layers construct which can be divided into layers based on complex social phenomena's observability and accessibility. Organizational culture has been described as patterns of shared values and beliefs over times which develop behavioural norms that are adopted and implemented in solving problems. The Organizational culture represents the organization's internal environment and it is constructed by the assumptions and beliefs or managers and employees. Organizational culture that is constructed from people's belief, assumptions, values, attitudes, and behaviors is a valuable source of organization's competitive advantage, it will provide solutions to problems faced by the organization and thus it will help the organization in reaching its goals. (Ul Mujeeb Ehtesham, Tahir Masood Muhammad, Shakil Ahmad Muhammad, 2011). Robbins (2011) defines organization culture as a system of shared meaning held by the organization's members that differentiate the organization from other organizations. Kreitner \& Kinicki (2010) also defines organizational culture as a set of shared, taken for granted implicit assumptions that a group holds and that determines, how it perceives, thinks about, and reacts to various environments. . It also defines the shared pattern in organization culture will help the organization in solving the problems of external adaptation and internal integration. 
Organizational Culture is also taken as a consideration in decision making of long term strategic planning. It states that organizational culture that manifest itself in specific behavior will drive the market oriented behaviors which normally take place in organizations' strategy maps (Aydin \& Ceylan, 2009).As general perception of the organization's members has, represent the organizational culture, therefore we should know that people with different backgrounds or levels in the organization will tend to describe its culture. Many large organizations have a dominant culture (expressed by the core values shared by majority of organization's members) and numerous sub culture (expressed by group of members in some department). If the organization is only constructed by only of numerous subcultures, then organizational culture will be less powerful as independent variable.

Based on these definitions, a group of people who work together in the same organization need a set of rules to act in general manner. They need to know as well how to act in certain circumstances. Thereby it will help the organization's member to be united and under the same umbrella on reaching organization's goal.

The organizational culture is a quite complex concept yet it is widely accepted. The dimensions of organizational culture are many; it comes from various literature perspectives. From various finding and in accordance with my research, the dimensions of organization culture will be selected based on study findings of Bulent Aydin and Adnan Ceylan (2009) and in elaboration with Denison's framework which are as follows:

1. Involvement: Giving favorable conditions where all organization's members have an opportunity for decision making and giving various ideas, suggestions, and recommendations.

2. Collaboration: Emphasize on teamwork rather than individual work.

3. Transmission of information: Transmitting new or important information to members in due time.

4. Learning: Set of activities in order to increase and develop the existing knowledge, skills and ability.

5. Care about clients: Related with customers' satisfaction.

6. Strategic direction: Deals with how organization achieves its own plans and goals.

7. Reward and Incentive System: A scheme that provides members with reward and incentive to boost members' motivation.

8. System of Control: Assists the managers in supervising the team members.

9. Communication: Fundamental core of organization that build bridgesm among the team members within the organizations.

\section{Organizational Effectiveness}

Effectiveness is one fundamental concept in any organization. It is the degree or extent that the organization achieves its goals. Organizational effectiveness can be considered as quantitative and qualitative output and reflects the quality and output that associated with a broad range. In a competitive 
environment, the organizational effectiveness is one of the most important issues in management which can ensure continuity of organization life and survival. (Dizgah, 2011). Now the assessment of organizational effectiveness is an important topic for range of people, managers, stockholders, government agencies, and OB specialist. According to Kreitner \& Kinicki (2010), there are four generic criteria for organizational effectiveness and can be applied equally well to large or small and non-profit or profit organization. These criteria can be combined in various combination but the most important thing is there is no single approach to the effectiveness's evaluation is appropriate in all conditions or for all organizations. Four effectiveness criteria according to Kreitner \& Kinicki (2010) are as follows: Goal Accomplishment, Resource Acquisition, Internal Processes, and Strategic Constituencies Satisfaction. Effectiveness is measured as how well it works and achieves to its expected results. Thereby this will help the organizations to assess themselves as to how nearer it has approached to perfection. In congruence with the definition, the research is going to measure the organizational factors through four indicators which are as follows (Bulent Aydin, Adnan Ceylan 2009):

\section{Customer Orientation}

The main part of customer orientation is about thinking of customer's priorities. Being more customer-oriented will affect the organizational development and it will create effectiveness in organizations.

\section{Employee's Satisfaction}

Employee satisfaction can be defined as the combination of affective reactions to the differential perceptions of what she/he received compare to what she/he actually receives (Aydin \& Ceylan, 2009).

\section{Organizational Commitment}

Organizational commitment is the psychological strength of the relationship of a member to an organization.

\section{Financial and Growth Development}

The degree measure of company's financial health and growth performance is related

with the improvement of sales volumes, growth in market share, overall competitive position, general profitability, new product innovation, and budget $\&$ target achievement.

\section{Methodology}

This research uses a descriptive and a quantitative approach. Sugiyono (2012) defines a descriptive research approach as a statistic method which uses description technique to analyze data or to describe the collecting data without any intention to build a conclusion in general. A quantitative approach analyses the collected data by using a statistical method. In general, this study is conducted to analyses the correlation of organizational culture into organization effectiveness of Hotel-X Jakarta within each relevant dimensions. Type and source data is divided into two parts which are primary and secondary data (Cooper \& Schindler, Business Research Method 11th Edition, 2011). Primary data collected by research object, in this case is the employees of Hotel-X Jakarta. secondary data is used mainly from respective journals, books, articles and others to identify 
and the research background, problems, theories and the process of analyzing the data. Population is all employees from various level and departments of Hotel-X Jakarta. The sampling method used is Stratified-random sampling where the respondents are the population is divided into sub population based on "strata". In this case the "strata" of Hotel-X Jakarta is Rooms, F\&B, Revenue Management Center, Engineering, A\&G, Security, Human Resources and Finance. Apart from that, convenience method is also used to get the samples easier. The population size of Hotel-X Jakarta is determined and known. Hence, the Slovin's formula used to determine the sample size. Due to the population of Hotel-X Jakarta is 430 , with a 10 percent margin error, then the determination of sample size is 81,13 . To conclude, the minimum sample size needed for this research is 81 samples. But as the requirement of SEM analysis is minimum 100 hundred samples, so this research requires a minimum of 100 samples. Based on requirement, 128 samples were successfully collected from Hotel-X Jakarta.

\section{Research Model}

The research model in the figure below illustrates the relationship between Organizational Culture and Organizational Effectiveness.

Figure 1. Research Model

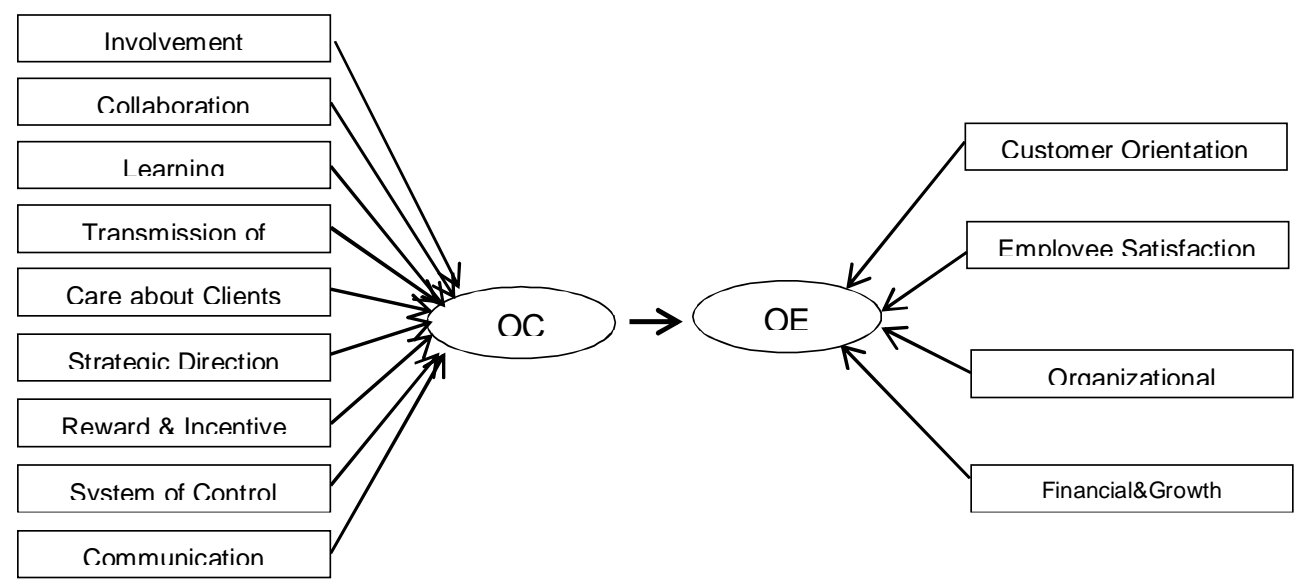

\section{Hypothesis and Preposition}

\section{Hypothesis \#1}

$\mathbf{H}_{1-0}$ : Organizational Culture Influences Organizational Effectiveness.

$\mathbf{H}_{1-1}$ : Organizational Culture does not influence Organizational Effectiveness.

\section{Proposition \#1}

$\mathbf{P}_{1-0:}$ The dimension of Organization Culture that has the strongest effect on Organizational Effectiveness is "strategic direction".

$\mathbf{P}_{1-1:}$ The dimension of Organization Culture that has the strongest effect on Organizational Effectiveness is not "strategic direction". 


\section{Data Analysis}

The method of analysis is quantitative. Beforehand a pre - test was conducted with a sample 30 respondents; after that validity and reliability tests was conducted to analyze the result of the pre-test. A post-test was also conducted with a sample as mentioned before in sample size section. The analysis methods that will be used are descriptive analysis and structural equation modelling (SEM) analysis.

\section{Result and Discussion}

\section{Descriptive Analysis}

Below is provided the descriptive statistic table which show the descriptive characteristic of each dimension of organizational culture and effectiveness,

\section{Descriptive Statistics}

\begin{tabular}{|c|c|c|c|c|c|}
\hline & $\mathbf{N}$ & Minimum & Maximum & Mean & Std. Deviation \\
\hline I & 128 & 2.0 & 5.0 & 4.051 & .5947 \\
\hline $\mathrm{C}$ & 128 & 2.5 & 5.0 & 4.027 & .6439 \\
\hline TI & 128 & 1.5 & 5.0 & 2.984 & .6785 \\
\hline $\mathrm{L}$ & 128 & 2.6667 & 5.0000 & 4.221354 & .5007035 \\
\hline $\mathrm{CC}$ & 128 & 2.25 & 5.00 & 4.0137 & .61262 \\
\hline SD & 128 & 2.50 & 5.00 & 3.9258 & .56153 \\
\hline RIS & 128 & 1.6667 & 5.0000 & 3.609375 & .7425446 \\
\hline $\mathrm{SC}$ & 128 & 2.0 & 5.0 & 3.250 & .5919 \\
\hline COM & 128 & 1.0 & 5.0 & 3.918 & .7550 \\
\hline $\mathrm{ES}$ & 128 & 2.6000 & 5.0000 & 3.704687 & .5645512 \\
\hline ORC & 128 & 1.50 & 5.00 & 3.6309 & .69444 \\
\hline $\mathrm{CO}$ & 128 & 2.8333 & 5.0000 & 3.984375 & .5129289 \\
\hline $\mathrm{FG}$ & 128 & 1.0000 & 5.0000 & 3.708333 & .6822330 \\
\hline $\begin{array}{l}\text { Valid } \\
\text { (listwise) }\end{array}$ & $N{ }_{128}$ & & & & \\
\hline
\end{tabular}

Table 1

:Descriptive Statistic(Source: SPSS - data Processing Result)

\section{Goodness of Fit Analysis}

\begin{tabular}{|l|l|l|l|}
\hline Fit Criteria & Standard Ratio & Result & Evaluation \\
\hline CMIN & As low as possible & 179.315 & Moderate fit \\
\hline CMIN/df & $\begin{array}{l}\text { As low as 2,00 and } \\
\text { as high as 5,00 }\end{array}$ & 2.892 & Good Fit \\
\hline GFI & Close to 1 & .798 & Moderate Fit \\
\hline AFGI & Close to 1 & .704 & Moderate Fit \\
\hline RMR & As low as possible & .035 & Good Fit \\
\hline CFI & Close to 1 & .744 & Moderate Fit \\
\hline RMSEA & $\leq 5$ & .128 & Good Fit \\
\hline
\end{tabular}

Table2:Goodness of Fit Model(Source: AMOS - Data Processing Result) 
Based on table above, it shows that the SEM model has meet with the goodness of fit criteria. That means the SEM model already fit with the sample data. The value of GFI, AFGI, and CFI are also in range which usually called moderate fit.

\section{Direct Effect, Indirect Effect, Total Effect Analysis}

Each latent variable has an effect on other variables directly or indirectly. In this research, the direct, indirect, and total effect analysis comes from the standarized direct, indirect and total effect output, which can be seen on below table:

\begin{tabular}{|l|l|l|l|}
\hline Variables & Direct Effect & Indirect Effect & Total Effect \\
\hline OC ---> OE & .932 & .000 & .932 \\
\hline
\end{tabular}

Table 4: Direct, indirect, and total effect analysis

(Source: AMOS - Data Processing Result)

Table above states that variable OC (Organizational Culture) has a direct effect on variable OE (Organizational Effectiveness) with a value of 0.932 . Hence, the total effect value is 0.932 .

Dimension Factor Loading Analysis

The dimension factor loading analysis of each variable is shown on table below:

\begin{tabular}{|c|c|c|c|}
\hline Variables & Dimensions & $\begin{array}{l}\text { Factor Loading } \\
\text { Value }\end{array}$ & \\
\hline \multirow{9}{*}{$\begin{array}{l}\text { OC } \\
\text { (Organizational } \\
\text { Culture) }\end{array}$} & $\begin{array}{l}\text { SD (Strategic } \\
\text { Direction) }\end{array}$ & 0.706 & \multirow[t]{9}{*}{ MAX } \\
\hline & $\begin{array}{l}\text { CC (Care about } \\
\text { Clients) }\end{array}$ & 0.648 & \\
\hline & $\begin{array}{l}\text { RIS (Reward and } \\
\text { Incentive System) }\end{array}$ & 0.542 & \\
\hline & $\begin{array}{l}\text { COM } \\
\text { (communication }\end{array}$ & 0.530 & \\
\hline & $\mathrm{C}$ (Collaboration) & 0.504 & \\
\hline & I (Involvement) & 0.463 & \\
\hline & L (Learning) & 0.384 & \\
\hline & $\begin{array}{l}\text { SC (System of } \\
\text { Control) }\end{array}$ & 0.344 & \\
\hline & $\begin{array}{l}\text { TI( Transmission } \\
\text { of Information) }\end{array}$ & 0.132 & \\
\hline \multirow{4}{*}{$\begin{array}{l}\text { OE } \\
\text { (Organizational } \\
\text { Effectiveness) }\end{array}$} & $\begin{array}{l}\mathrm{CO} \text { (Customer } \\
\text { Orientation) }\end{array}$ & 0.737 & \multirow[t]{4}{*}{ MAX } \\
\hline & $\begin{array}{l}\text { FG (Financial \& } \\
\text { Growth } \\
\text { Development) }\end{array}$ & 0.727 & \\
\hline & $\begin{array}{l}\text { ES (Employee } \\
\text { Satisfaction) }\end{array}$ & 0,684 & \\
\hline & $\begin{array}{l}\text { ORC } \\
\text { (Organizational } \\
\text { Commitment) }\end{array}$ & .126 & \\
\hline
\end{tabular}


Table 5: Indicator Factor Loading Analysis Source: AMOS

The analysis of Table $5: 1$ ) From the variable organizational culture (OC), dimension SD (strategic direction) has the biggest factor loading with a value of 0.706 , followed by dimension CC (care about clients) with a value of 0.648 , dimension RIS (reward and incentive system) with a value of 0.542 , then dimension Com (communication) with a value of 0.530 , and dimension $\mathrm{C}$ (collaboration) with a value of 0.504 . Some dimension $\mathrm{s}$ of organization culture also have low factor loading which are dimension Involvement (0.463), Learning (0.384), and dimension System of Control (0.344). The Transmission of Information (TI) has the lowest value of indicator factor loading (0.126) towards the organization culture.

a) Strategic Direction influences $\mathrm{OC}$ at $70.6 \%$. It appears that the organization's culture of The Hotel-X Jakarta has been influenced more by SD (strategic direction).Theory (Aydin \& Ceylan, 2009) states that strategic direction indicates that organization has a clear strategic direction such as goals, vision, and mission to achieve organization's goals. With the highest value, it shows that The Hotel-X Jakarta has made a lot of efforts in creating a clear strategic direction and in implementing that strategy. In fact, The Hotel-X Jakarta has some meetings which influence the high value of strategic direction, such as annual goal setting value meeting, monthly operational meeting, monthly direct line meeting between managing directors and subordinates, and even the daily morning briefing. These facts clearly show strategic direction that has been applied thoroughly in all of the hotel operations.

b) Care about Clients influences OC at $64.8 \%$. It is the second biggest factor which influences the organization culture of The Hotel-X Jakarta with a value of 0.648. It means The Hotel-X Jakarta as an organization always tries to improve their quality, innovating to fulfill customer expectations and needs, and achieving high customers' satisfaction. It can be proved from the fact that The Hotel-X Jakarta has a glitch comment report that record all the guests' feedback to be reviewed monthly for improvement.

c) Reward and Incentive System Influences OC at $54.2 \%$. The correlation between RIS and OC is at 0.542 . The value indicates that the Hotel-X has a clear reward and incentive system to motivate their employees such as employee of the year, incentives from room sales, etc. It is also supported by the theory of Bulent Aydin and Adnan Ceylan (2009) that RIS is one dimension of OC that refers to an organization that has a scheme to reward and give incentives correctly to motivate employees.

d) Communication Influences $\mathrm{OC}$ at 53\%. The Communication influences organization culture at the stage of 0.53 . As communication refers to the core that builds bridge between organization/managers to team members, the result (considered as moderate high) means communication has played quite a big role in building the organization's culture, and strengthening the relationship between employees especially between team members with supervisors in achieving the organizational effectiveness.

e) Collaboration influences $\mathrm{OC}$ at $50.4 \%$. The influence of indicator toward $\mathrm{OC}$ is at $50.4 \%$. As the value shown is also quite high, it means in The Hotel-X Jakarta, the organization is focused more on teamwork rather than individual work 
in achieving organizational effectiveness. The more the organization emphasize on teamwork, the stronger the organizational culture will be.

f) Involvement influences OC at $46.3 \%$. It states the correlation between involvement and OC is at $46.3 \%$. Involvement refers to where the organization's members have the opportunity to involve themselves such as decision making, giving ideas, etc in their daily working routines (Aydin \& Ceylan, 2009). As the value is not that high, any involvement opportunity such as more empowerment $\&$ better working condition will foster the organizational culture.

g) Learning influences OC 38.4\%. Based on analysis, learning influences OC at $38.4 \%$. Based on Aydin \& Ceylan's theory (2009) and from Denison's Consulting, it states dimension learning is quite important to increase employee's capability development that can create higher organizational performance which can lead to organization effectiveness. As the value is relatively low (0.384), it means The Hotel-X Jakarta needs to add more training courses and improve training quality.

h) System of Control influences OC at $34.4 \%$. The correlation between SC to $\mathrm{OC}$ is at $34.4 \%$. The theory from Aydin \& Ceylan (2009) says that SC refers to a clear system that assists managers in supervising the team members. Based on the analysis the result is relatively low, which means The Hotel-X Jakarta needs to develop their system to gain better control of their employees to lead to stronger organizational culture.

i) Transmission of Information insignificantly influences OC. With a probability value of Transmission of Information of 0.208 (above 0.05), it can be concluded that the transmission of information insignificantly influences the culture of The Hotel-X Jakarta. As appears from the model, the Communication factor influences Organization Culture at 0.53 value, which means the organization's communication in the Hotel-X Jakarta runs smoothly and effectively between departments, which resulted in excellent organization performance in aiming the organizational effectiveness.

2. CO (Customer Orientation) has the biggest factor loading with a value of 0.737 , then followed by dimension FG (Financial \& Growth Development) with a value of 0.727 , then followed by dimension ES (Employee's Satisfaction) with a value of 0.684 then dimension ORC (organizational Commitment) with a value of 0.126 . The percentage influence of each dimension to organizational effectiveness is explained below.

a) Customer orientation influences $\mathrm{OE}$ at $73.7 \%$. Based on analysis, the correlation between customer orientations to organizational effectiveness is positive with a value of 0.737 . Customer orientation is the set of belief that put customers into the centre and this dimension can affect organizational development and create effectiveness (Aydin \& Ceylan, 2009). According to the results, The Hotel-X Jakarta itself shows that the organization is very customer oriented and in line with the analysis result of dimension CC (care about clients) of their organizational culture.

b) Financial \& growth development influences OE at $72.7 \%$. The correlation between FG to $\mathrm{OE}$ is at $72.7 \%$. According to result, it is considered as high. This means there is no problem in regards to the organization's financial health and growth performance. The more the organization improves sales and strengthen 
financial \& growth development, organizational effectiveness will become stronger.

c) Employee Satisfaction influences OE at $68.4 \%$. Based on the analysis, it indicates $68.4 \%$ of organizational effectiveness can be measured from employees' satisfaction. As the correlation is positive, it means there is a significant positive influence and it indicates The Hotel-X Jakarta is able to fulfill employee's expectations. Howeer it needs to be improved to create higher influence on OE, as supported from Aydin and Ceylan's theory of organizational effectiveness (2009), the well-satisfied employee will create more productivity and create more effectiveness to organization.

d) Organizational Commitment insignificantly influences to OE. According to SEM model interpretation result, the $p$ value of ORC to $\mathrm{OE}$ is above 0.05 $(0.225>0.05)$. This means there is no significant influence of organizational commitment on organizational effectiveness in The Hotel-X Jakarta. Related to the employee satisfaction factor which appears quite high, with a value of 0.684 , it can be concluded that most of the employees are satisfied with their work environment and comfortable with it. Therefore, indirectly, organizational commitment does not appear to be the factor that influences the effectiveness of the organization as the employee satisfaction factor already creates a huge impact on organizational performance.

\section{Hypothesis and Proposition Analysis}

\begin{tabular}{|l|l|l|l|lr|}
\hline Variables & $\begin{array}{l}\text { Hypothesis \& } \\
\text { Proposition }\end{array}$ & $\begin{array}{l}\text { Standardized } \\
\text { Estimation }\end{array}$ & P-Value & Result \\
\hline $\mathrm{OC} \rightarrow \mathrm{OE}$ & $\mathrm{H}_{1}$ & 0.935 & $* * *$ & $\begin{array}{l}\mathrm{H}_{1-0} \text { is } \\
\text { accepted }\end{array}$ \\
\hline $\mathrm{SD} \rightarrow \mathrm{OC}$ & $\mathrm{P}_{1}$ & 0.706 & $* * *$ & $\begin{array}{l}\mathrm{P}_{1-0} \text { accepted } \\
\text { is }\end{array}$ \\
\hline
\end{tabular}

Table 6 : Hypothesis and Proposition Analysis (Source: AMOS)

\section{Hypothesis \#1}

According to table OC (organization culture) has a positive significant influence toward OE (organizational effectiveness) with a standardized estimation value of 0.935 . It is stated that the $\mathrm{p}$-value is $* * *$, which means the OC has a very significant positive influence on $\mathrm{OE}$. Thus, in this research hypothesis $\mathrm{H}_{1-0}$ is accepted.

Based on the analysis, it matches and is in line with the theory and previous study as it is said that OC helps organization members to work together under the same circumstances and effectively in reaching organization's goals which means OC gives contribution for employees to reach maximum effectivity of organization's performance (Aydin \& Ceylan, 2009).

Preposition\#1: SD (Strategic Direction) has the biggest factor loading value of 0.706 which means it has the strongest factor of OC (organization culture). The Pvalue is also ***, which means SD has a very significant positive influence to OC. Therefore, it concludes that proposition $\mathrm{P}_{1-0}$ is accepted.

Based on analysis, it is matched and in line with the previous study from study (Aydin \& Ceylan, 2009), where it is also clearly stated that strategic direction is the strongest factor to $\mathrm{OC}$ in reaching $\mathrm{OE}$. 


\section{Conclusion and Recommendation}

\section{Conclusion}

1. There is a significant positive influence between Hotel-X Jakarta's organizational culture and organizational effectiveness. Based on data processing using SPSS 20 and with SEM data analysis, variable OC of Hotel-X Jakarta influences variable $\mathrm{OE}$ at $93.2 \%$. This number is considered as high influence. This is in line with theory and previous study, as organizational culture is a very important asset of an organization that can lead to good organizational development which creates greater effectiveness.

2. Based on SEM model and indicator factor loading analysis, it is concluded that dimension SD (strategic direction) has the biggest factor loading value of 0.706. The p-value of SD is also *** which means the indicator SD very significantly influences OC in reaching organizational effectiveness.

Based on the previous study by Aydin \& Ceylan (2009), an effective organization can be described as an organization that provides employee's satisfaction, organizational commitment and customer orientation to all of employees. To create this implication, a good communication and coordination is required. Good communication will be created if there is a good organizational culture as the formed culture lets the members understand and work effectively under the same conditions. From the result, it is shown that Hotel-X Jakarta has managed to create a well-formed organizational culture, they concerns with every member of the organization and its culture as it creates organizational effectiveness This concludes why organizational culture of Hotel-X Jakarta is fully related to organizational effectiveness or it can be said that organizational culture assists the organization in reaching organizational effectiveness.

\section{Recommendation}

It is concluded that Organizational Culture is highly related to organizational effectiveness. However due to the scope and limitation of the study as well as the result of statistical analysis of each dimension of $\mathrm{OC}$ and $\mathrm{OE}$, it can be recommended that:

1. From the Output of SEM Model, It is stated that some dimensions of OC have low influence. These are: Involvement (46.3\%), Learning (38.4\%), and System of Control (34.4\%). This means the organization needs to be more concerned with these dimensions as the improvement of these dimensions will improve organizational culture that can lead to better organizational effectiveness. Improvement of these dimensions can be done by for example: giving more training \& empowerment to the staff, improving training quality, and updating the control system of the hotel.

2. From the SEM output as well, some dimensions of OC have significant and relatively high influence. These are: Strategic Direction (70,6\%), Care about clients $(64,8 \%)$, Reward and Incentive System (54.2\%), Communication (53\%) and Collaboration $(50,4 \%)$. These dimensions really enhance the strength of Hotel-X Jakarta's organizational culture. Hence it is recommended for the 
organization to always maintain, oversee, and even give improvement to each of these strong dimensions, in order to create a greater effectiveness and to avoid weak culture.

3. Based on output as well, it is well concluded that the Organizational culture really significantly influences organizational effectiveness. Thus it is recommended for Hotel-X Jakarta and other hotels to know maintain and form their culture better as it is already proved that OC highly influence OE which can lead to organizational development. For instances, Hotel-X Jakarta should do socialization about their corporate culture to every organization's members especially newcomers to strengthen its organizational culture.

4. Due to a very little attention given to this study, specifically in hotel sector in Jakarta, Indonesia. It is recommended for further research of this study (the effect of $\mathrm{OC}$ to $\mathrm{OE}$ ). As this study only researched on a local independent five stars hotel, it might give result discrepancies if it's applied on international hotel chain, local hotel chain, budget hotel, and any other special type of hotel.

5. The researcher mainly used the theory of organizational culture \& effectiveness theory by Adnan Ceylan \& Bulent Aydin (2009). It is known there are many theories of organization culture, thus it is recommended to use or combine others' theory perspective of OC \& OE for further research

6. It is also recommended to do further research in different industries and areas. Due to the scope and limitations, this research is only applicable to specific hotel industry in Jakarta, thus it might give a different result if it's conducted on other industry and area.

\section{REFERENCES}

Aydin, B., \& Ceylan, A. (2009). A Research Analysis on Employee Satisfactionin terms of Organizational Culture and Spiritual Leadership. International Journal of Business and Management, Vol.3 No.3.

Aydin, B., \& Ceylan, A. (2009). The Role of Organizational Culture on Effectiveness. Ekonomika A Management, Vol.3 , 33-48.

Cooper, D. R., \& Schindler, P. R. (2011). Business Research Method 11th Edition. New York: McGraw - Hill/Irwin.

Denison. (2014). The Denison Organizational Culture Model. Retrieved May 25, 2014, from Denison Consulting: http://www.denisonconsulting.com/model/organizational-culture

Dizgah, M. R., Chegini, M. G., Farahbod, F., \& Kordabadi, S. S. (2011). Employee Empowerement and Organizational Effectiveness in The Executive Organization. Journal of Basic and Applied Scientific Research, 974-980.

Dwimantika, C. (2011). Strategic Implementation Analysis of Asean Mutual Recognition Agreement in Hotel Industry towards Human Resources Global Competitiveness. Case Study: Jakarta 5 Star Hotels. Jakarta. 
Ehtesham, U. M., Muhammad, T. M., \& Muhammad, S. A. (2011). Relationship between Organizational Culture and Performance Management Practices: A case of University in Pakistan. Journal of Competitiveness, Issue 4 , 79-86.

Fikri, S. (2013). Cinematographic Tourism as Modern Tool in Tourism Marketing with Case Study: 'Eat Pray Love' Movie. Jakarta.

Hair, J., Bush, R., \& Ortinau, D. (2010). Marketing Research: Within a Changing Information Environment. New York: McGraw-Hill/Irwin.

Hooper, D., Coughlan, J., \& Mullen, M. (2008). Structural Equation Modelling: Guidelines for Determining Model Fit. Electronic Journal of Business Research Method Vol. 6, Issue 1, 53-60.

Kreitner, R., \& Kinicki, A. (2010). Organization Behavior. New York: McGrawHill/Irwin

Lejeune, C., \& Vas, A. (2009). Organizational Culture and Effectiveness in Business Schools: A test of the Accreditation Impact. Journal of Management Development, Vol.28 No.8, 728-741.

Muktiono, D. (2013). Influence of Organizational Culture on Organizational Citizzenship Behavior: A Case Study of Redtop Hotel, Jakarta. Jakarta.

Robbins, S. P., \& Judge, T. P. (2011). Organizational Behavior. Pearson.

Sugiyono. (2012). Metode Penelitian Kuantitatif Kualitatif dan $R \& D$. Bandung: Alfabeta.

Wijaya, T., \& EQ, M. Z. (2012). Panduan Teknik Statistik SEM \& PLS dengan SPSS AMOS. Yogyakarta: Cahaya Atma Pustaka. 